\title{
RELATIONSHIP OF GERMINATION AND ESTABLISHMENT FOR TWELVE PLANT SPECIES IN RESTORED DRY GRASSLAND
}

\author{
KÖVENDI-JAKÓ, A. ${ }^{1 *}$ - CSECSERITS, A. ${ }^{2}$ - HALASSY, M. ${ }^{2}$ - HALÁSZ, K. ${ }^{2}$ - SZITÁR, K. ${ }^{2}$ - TÖRÖK, K. ${ }^{2}$ \\ ${ }^{1}$ Eötvös Loránd University, Department of Plant Taxonomy, Ecology and Theoretical Biology \\ Pázmány P. stny. 1/C, 1117 Budapest, Hungary \\ (phone: 06-1-381-2187, fax: +36-1-381-2188) \\ ${ }^{2}$ Centre for Ecological Research, Institute of Ecology and Botany \\ Alkotmány u. 2-4, 2163 Vácrátót, Hungary \\ (phone: +36-28-360-122; fax: +36-28-360-110) \\ *Corresponding author \\ e-mail: kovendi.jako.anna@gmail.com; \\ (phone: +36-1-381-2187; fax: +36-1-381-2188) \\ (Received $18^{\text {th }}$ Mar 2017; accepted $6^{\text {th }}$ Jun 2017)
}

\begin{abstract}
There is a lack of knowledge on germination capabilities of native species and their relation to field establishment that could help optimize ecological restoration efforts. We studied laboratory germination and second year field establishment of 12 native vascular dry grassland plant species in the frame of a restoration project in NE Hungary. Our questions are:1) For which species is cold-stratification necessary to break dormancy of seeds? 2) Is there a positive correlation between germination and second year establishment? Laboratory germination was studied with and without cold-stratification and the impact of cold-stratification was tested by linear model. Relationships between germination and field establishment were tested by generalized linear models. Cold-stratification decreased significantly the germination of four grass species, and was important to break dormancy for one dicot. Field establishment is positively connected with germination under both germination treatment. We conclude that, laboratory germination has a high predictive value on the establishment success of seeded species.

Keywords: cold-stratification, field plant cover, germination percentage, Hungary, sandy grassland
\end{abstract}

Nomenclature: Scientific plant names follow the nomenclature of Király (2009).

\section{Introduction}

The unprecedented loss of biodiversity and the degradation of habitats justifies the need for ecosystem restoration, which is currently acknowledged at the policy level (Aronson and Alexander, 2013; Suding et al., 2015) and as a result, large-scale restoration efforts are planned (Aichi Target 15, SCBD, 2011). To support this volume of restoration need, the use of seeds of native species has to be scaled up and survival success has to be increased (Merritt and Dixon, 2011). Difficulty in achieving scaling up lies partly in the lack of sufficient amount of seeds and wasting by seeding more than necessary in the hope of restoration success (Williams et al., 2002; Hedberg and Kotowski, 2010; Merritt and Dixon, 2011). The other limitation of restoration is that seeding often fails to reach restoration target (Pyke et al., 2013) due to scattered knowledge on requirements of early life stages of reintroduced plant species (Larson et al., 2015). The early stages of plant recruitment are essential in the reestablishment of wild species at restoration areas as high mortality occurs during this period (James et al., 2013; Carrington, 2014). Advancements in the science of seed ecology and early life stage characteristics of plants is needed to 
underpin restoration success (Commander et al., 2009; Larson et al., 2015) and help to assess seed amount in future restoration planning.

Spontaneous succession is often hindered by the lack of seeds that originates from the depletion of soil seed bank and limited seed dispersal (Kiehl et al., 2014). Seed introduction methods to overcome this limitation include among others direct seeding, diaspore transfer with substrate, hay or brush harvesting, slot seeding, plug planting (Hedberg and Kotowski, 2010) or, under extreme conditions, e.g. in Mediterranean areas hydroseeding (Sheldon and Bradshaw, 1977; Oliveira et al., 2012). Direct seeding is the most widely used restoration method (Kiehl et al., 2010; Török et al., 2011). The composition of a seed mixture is dependent on the condition of the restoration site, the availability of seeds of target species (Török et al., 2011) or their dominance in the target vegetation (Hedberg and Kotowski, 2010). Commercial seed mixtures can be purchased easily and in large quantity. However adverse climatic and soil conditions can hinder their establishment or if established, highly competitive, fast-growing species can constrain further vegetation development (García-Palacios et al., 2010). In contrast, difficulty in using native seeds lies in the lack of seed market or scarce information on seed biology (Commander et al., 2009).

Germination is a critical transition influencing survival after seeding (Larson et al., 2015; Gallagher and Wagenius, 2016). Without knowledge on germination characteristics, the necessary amount of seeds for restoration cannot be properly estimated. Germination is generally studied under laboratory or greenhouse conditions by testing germination percentage (Grime et al., 1981; Haslgrübler et al., 2013; Larson et al., 2015; Gallagher and Wagenius, 2016). Knowledge gained during these experiments can be exploited in restoration to estimate the necessary amount of seeds; to identify best seeding time for different species based on cold-stratification requirements (Jones and Kaye, 2014), or optimal pre-treatment of seeds (Krock et al., 2016). Seed dormancy, a key attribute in the diversification of seed plants is another critical determinant of establishment success (Willis et al., 2014), and thus influences species distribution (Donohue et al., 2010). In order to enhance restoration success, breaking dormancy is a key issue. Physiological seed dormancy is the most common type of dormancy (Baskin and Baskin, 2004). Non-deep physiological seed dormancy might be broken by cold-stratification treatments (Baskin and Baskin, 2004; Krock et al., 2016), with an optimal dormancy breaking time between 2 to 12 weeks (Jones and Kaye, 2015; Kaur et al., 2016). Krock et al. (2016) investigated ten prairie species and discovered the optimal cold-stratification time below the standard protocol guidelines at eight species, they suggest 15 to 60 days of treatment. In the seed germination database of Hungary, eight of the twelve species involved in our study were pre-treated by coldstratification of 1 week (Peti et al., 2017). There is a lack of knowledge concerning the relationship of germination ability and establishment of herbaceous plants that are most widely used in vegetation restoration (Carrington, 2014). Species must first be able to germinate to establish (Willis et al., 2014) thus producing seedlings that are prone to further mortality losses. Larson et al. (2015) have disentangled the relative importance of physiological and morphological traits that influence germination and early recruitment success for several species, but the time span of their experiment has not expanded over three weeks. Oliveira et al. (2012) found that the germination ability of single species cannot predict the behaviour in multispecies situations as co-seeding of species with various traits can have adverse results. The early seedling stage is critical under field conditions, given the stochastic nature of early recruitment events and high 
mortality in the first summer (De Steven, 1991; Oliveira et al., 2012), establishment by the end of the first growing season is an important milestone to predict restoration success (Clarke and Davison, 2004; Kiehl et al., 2014; John et al., 2016). However, little is known on later stages of seeded species. Only few studies have compared early life stage transition and second year field establishment in grassland restoration projects (Kotorová and Lepš, 1999; Clarke and Davison, 2004).

In this study, we attempt to link germination ability to second year field establishment. We analyse twelve grassland species native to the Pannonian ecoregion that are used, among others in a restoration project at a factory site in NE Hungary. The following questions are addressed: 1) For which species is cold-stratification necessary to break dormancy of seeds? 2) Is there a positive correlation between germination and second year establishment?

\section{Materials and methods}

\section{Study area}

The restoration experiment is located in NE Hungary, in the acidic inland sand dune region of Nyírség (lat $47^{\circ} 57^{\prime} \mathrm{N}$; long $21^{\circ} 39^{\prime} \mathrm{E}$ ). Annual average temperature is $9.8^{\circ} \mathrm{C}$, average precipitation is 550-600 $\mathrm{mm}$. The natural vegetation has been mostly transformed by human use, resulting in the loss of natural habitats and the expansion of invasive species (e.g. Asclepias syriaca, Robinia pseudo-acacia, Botta-Dukát (2008)). The construction of a new factory enabled us to carry out an experiment with the aim to restore native vegetation at the factory area (approx. 7 ha). Target communities are open (Festuco vaginatae - Corynephoretum Aszód (1935), priority habitat: 6260 Pannonic sand steppes (Romão, 1996)) and closed sandy grasslands (Pulsatillo hungaricae Festucetum rupicolae Borhidi (1996), Potentillo arenariae - Festucetum pseudovinae Soó (1940), priority habitat: 6260 Pannonic sand steppes (Romão, 1996)). The site was used as agricultural field, mostly apple orchard prior to the construction. The closest semi-natural dry grassland is $2.5 \mathrm{~km}$ far from the factory at a kurgan.

Grassland reintroduction started in 2014 in the form of seeding (with the application of mulch) or hay transfer. Two fescue species were seeded in larger quantities (Festuca rupicola, $F$. pseudovina) as matrix species. Altogether 45 native plant species were introduced in September 2014 as seed in different amount. Seeds originated from different sources including cultivated and wild forms (details in Table 1). Here we report on the seedings in two restoration parcels: NW1 seeded by purchased cultivated species and $\mathrm{S}$ seeded by collected species. The collected seeds included the self-collected and purchased collected seeds in this study. For the map of restoration area see Figure 1.

\section{Studied species}

Measurements of all seeded species were not feasible because of the limited amount of seed lots. Therefore, seed mass and germination of twelve native species were investigated in the present study under laboratory conditions and compared with establishment in the field. Principle for species selection was that the sample should represent all three seed origin types (seeds purchased from cultivators, self-collected and purchased collected seeds), grasses and forbs. For further details on the species, please see Table 1 . 


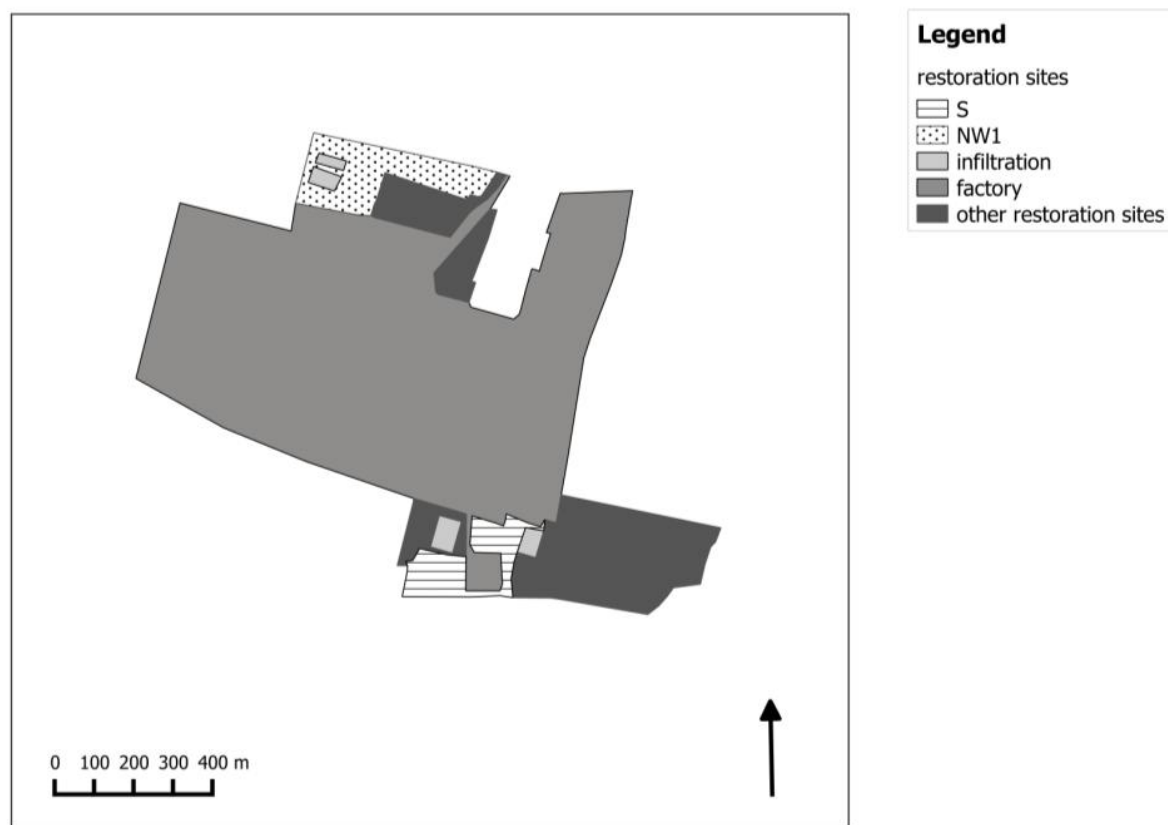

Figure 1. Map of restoration parcels and treatments within the factory. Establishment of species was estimated in two restoration parcels (named by NWI, S) seeded with 1) cultivated plants (NW1); and 2) collected seeds (S). The collected seeds included the self-collected and purchased collected seeds in this study. In the latter case the amount of hand-collected seeds was not enough to seed the whole parcel, therefore only seven smaller patches were seeded, marked by yellow line. Species list and seeding rates are listed in Table 1.

\section{Laboratory study}

All seeds were harvested in the summer and autumn of 2013 or 2014. Seeds were cleaned and stored at dry conditions (temperature: $25 \pm 3{ }^{\circ} \mathrm{C}$, humidity: $38 \pm 4 \%$ ) until the beginning of the germination experiment. All species involved in the study have orthodox seeds, so their long-term viability can be conserved under dry and cool circumstances (Hong and Ellis, 1996). Laboratory tests were carried out on samples from thoroughly mixed, dry seeds. Visibly fertile seed samples of $8 \times 100$ seeds of each species were counted in January 2015. The dry weight of 100 seeds was measured with $0.0001 \mathrm{~g}$ accuracy using an analytical balance. The values of seed mass were calculated as the average of 8 sample results. Laboratory germination of 100 seeds with four replicates per species was tested with and without cold-stratification (Hendry and Grime, 1993; ISTA, 2015). Samples of 100 seeds / Petri-dishes were placed on sterile, wet filter paper. The surface of seeds was not sterilised. Seeds under cold-stratification were placed in refrigerator at $4{ }^{\circ} \mathrm{C}$ for a month (Grime et al., 1981; Hendry and Grime, 1993; ISTA, 2015). Seeds without cold-stratification and after cold-stratification were kept under room condition (temperature: $25 \pm 3{ }^{\circ} \mathrm{C}$, humidity: $38 \pm 4 \%$, light: $3051 \pm 939$ Lux). The germination experiment started in February 2015 (without cold-stratification), and in March 2015 (with cold-stratification). Seeds were watered by 1-2 $\mathrm{ml}$ distilled water every 1-2 days. Germination was defined as emergence of the radicle. The germinated seeds were counted weekly for four months and removed from Petri-dishes. 


\section{Field study}

Second year field establishment was estimated in June 2016 in the two restoration parcels (Figure 1). Five randomly placed $2 \mathrm{~m}$ x $2 \mathrm{~m}$ coenological plots per parcel were surveyed by visual estimation of cover (\%) by species. In case of species sown into patches, establishment estimation was made by population cover estimation within whole patches. As sowing densities ( $\mathrm{seed} / \mathrm{m}^{2}$, Table 1) differed between species, according to the availability of seeds, field establishment was calculated as the secondyear cover weighted by sowing densities.

Table 1. List of studied species with origin of seed samples and sowing densities. Seeds were collected in 2013 or 2014 and seeded in September 2014. Origin of seeds: P-seeds purchased from cultivators; $C P$ - purchased collected seeds; $C S$ - self-collected seeds.

\begin{tabular}{|c|c|c|c|}
\hline Species & Family names & Origin of seeds & $\begin{array}{c}\text { Sowing densities } \\
\text { in the field } \\
(\text { seed } / \mathbf{m} 2)\end{array}$ \\
\hline Achillea collina Becker ex Rchb. & Asteraceae & $\mathrm{CS}$ & 2534 \\
\hline $\begin{array}{c}\text { Corynephorus canescens (L.) } \\
\text { P.Beauv. }\end{array}$ & Poaceae & CS & 123 \\
\hline Festuca pseudovina Hack. & Poaceae & $\mathrm{P}$ & 7631 \\
\hline Festuca rupicola Heuff. & Poaceae & $\mathrm{CP}$ & 19496 \\
\hline $\begin{array}{c}\text { Festuca vaginata Waldst. et Kit. ex } \\
\text { Willd. }\end{array}$ & Poaceae & $\mathrm{CS}$ & 28 \\
\hline Galium verum $L$. & Rubiaceae & $\mathrm{P}$ & 147 \\
\hline Jasione montana $L$. & Campanulaceae & CS & 323 \\
\hline Poa angustifolia $L$. & Poaceae & $\mathrm{CS}$ & 4 \\
\hline Salvia nemorosa $L$. & Lamiaceae & $\mathrm{P}$ & 175 \\
\hline Salvia pratensis $L$. & Lamiaceae & $P$ & 63 \\
\hline Securigera varia (L.) Lassen & Fabaceae & $\mathrm{P}$ & 18 \\
\hline Silene vulgaris (Moench) Garcke & Caryophyllaceae & $\mathrm{P}$ & 122 \\
\hline
\end{tabular}

\section{Data analysis}

Linear model was used to assess the effect of species and cold treatment (explanatory variables) on germination percentage (response variable). Germination percentage was estimated based on four replicates of 100 seeds. This data fulfilled the assumptions of normality. Model residuals showed heterogeneity of variances, therefore generalized least squares (GLS) linear model (Zuur et al., 2009) was used by using the nlme package (Pinheiro et al., 2016) with varIdent variance structure that allowed for different residual spread for each level of the species variable. Finally, contrast package based on Wald test was used as post hoc test to prove for cold-stratification the significant differences within species (Kuhn et al., 2013).

The impact of seed germination with or without cold-stratification (explanatory variables) on field establishment (response variable) was analysed by two separate generalized linear models (GLMs) with Gaussian distribution and identity link function (Zuur et al., 2009). Average values of germination percentage per species were used. Field establishment was square root transformed before analyses to fulfil the assumptions of normality and homoscedasticity. All analyses were carried out in the R 3.3.1 statistical environment (R Core Team, 2016). 


\section{Results}

Seed mass was very different among species. From the studied forbs Jasione montana had the lowest (0.0155 g), and Securigera varia (4.0269 g) had the highest seed mass. As for the grasses, Corynephorus canescens had the smallest $(0.0544 \mathrm{~g})$ and Festuca vaginata had the largest seeds (0.5546 g) (Table 2).

Table 2. Seed mass, laboratory germination of studied species with or without coldstratification based on $4 x 100$ seeds and field coverage in 2016 (\% of total cover in the sampled plots and patches). Mean seed mass is expressed as thousand seed weight in $g$ (based on $8 \times 100$ seeds).

\begin{tabular}{ccccc}
\hline Species & $\begin{array}{c}\text { Seed mass } \\
\text { (mean } \pm \text { SE, g) }\end{array}$ & $\begin{array}{c}\text { Germination } \\
\text { with cold- } \\
\text { stratification } \\
\text { mean } \pm \text { SE } \mathbf{( \% )}\end{array}$ & $\begin{array}{c}\text { Germination } \\
\text { without cold- } \\
\text { stratification } \\
\text { mean } \pm \text { SE (\%) }\end{array}$ & $\begin{array}{c}\text { Field coverage } \\
\text { (\%) }\end{array}$ \\
\hline $\begin{array}{c}\text { Achillea collina } \\
\text { Corynephorus } \\
\text { canescens }\end{array}$ & $0.0727 \pm 0.0024$ & $71 \pm 2$ & $70 \pm 4$ & 1 \\
$\quad$ Festuca & $0.0544 \pm 0.0035$ & $18 \pm 2$ & $41 \pm 2$ & 0 \\
pseudovina & $0.3931 \pm 0.0039$ & $91 \pm 1$ & $95 \pm 1$ & 47 \\
Festuca rupicola & $0.1539 \pm 0.0027$ & $40 \pm 1$ & $63 \pm 4$ & 29 \\
Festuca vaginata & $0.5546 \pm 0.0102$ & $64 \pm 2$ & $78 \pm 3$ & 0.02 \\
Galium verum & $0.2991 \pm 0.0070$ & $6 \pm 1$ & $9 \pm 2$ & 0 \\
Jasione montana & $0.0155 \pm 0.0003$ & $79 \pm 1$ & $75 \pm 8$ & 0.03 \\
Poa angustifolia & $0.1939 \pm 0.0094$ & $35 \pm 3$ & $30 \pm 3$ & 0.01 \\
Salvia nemorosa & $0.6277 \pm 0.0098$ & $1 \pm 0$ & $1 \pm 1$ & 0.01 \\
Salvia pratensis & $1.7581 \pm 0.0741$ & $25 \pm 5$ & $16 \pm 1$ & 0 \\
Securigera varia & $4.0269 \pm 0.0615$ & $49 \pm 3$ & $48 \pm 4$ & 0.01 \\
Silene vulgaris & $0.5966 \pm 0.0200$ & $94 \pm 1$ & $89 \pm 1$ & 0.51 \\
\hline
\end{tabular}

All species germinated under laboratory conditions, but germination greatly differed (Table 2). The highest germination percentages (exceeding 90\%) were found for $F$. pseudovina and Silene vulgaris both with and without cold-stratification. Salvia nemorosa and Galium verum germinated in very low numbers (1-9\%) under both conditions. Significant interaction was detected between cold stratification and species $(\mathrm{F}=13.04, \mathrm{df}=11, \mathrm{p}<0.05)$ (Table 3).

Table 3. Effect of cold-stratification and species on germination percentage. Df, $F$ and $p$ values are the result of GLS model. Significant differences are given at $p<0.05$.

\begin{tabular}{cccc}
\hline Explanatory variables & df & F-value & p-value \\
\hline Cold-stratification & 1 & 7.54 & $<0.05$ \\
Species & 11 & 1869.76 & $<0.05$ \\
Cold-stratification x species & 11 & 13.04 & $<0.05$ \\
\hline
\end{tabular}

The results of post hoc test showed significant response to cold-stratification for five species. Cold-stratification decreased the germination success of four grass species significantly: Corynephorus canescens, Festuca pseudovina, F. rupicola and $F$. vaginata. Only one forb species, Silene vulgaris germinated better after the coldstratification (Table 4). 
Table 4. Effect of cold-stratification within species. $D f, F$ and $p$ values are the results of post hoc test, based on Wald test.

Significant differences are given at $p<0.05$, not significant results are marked by n.s.

\begin{tabular}{cccc}
\hline Species & t-value & df & p-value \\
\hline Achillea collina & 0.31 & 72 & n.s. \\
Corynephorus canescens & -8.91 & 72 & $<0.05$ \\
Festuca pseudovina & -2.39 & 72 & $<0.05$ \\
Festuca rupicola & -5.45 & 72 & $<0.05$ \\
Festuca vaginata & -4.06 & 72 & $<0.05$ \\
Galium verum & -1.30 & 72 & n.s. \\
Jasione montana & 0.48 & 72 & n.s. \\
Poa angustifolia & 1.21 & 72 & n.s. \\
Salvia nemorosa & -0.31 & 72 & n.s. \\
Salvia pratensis & 1.55 & 72 & n.s. \\
Securigera varia & 0.25 & 72 & n.s. \\
Silene vulgaris & 3.69 & 72 & $<0.05$ \\
\hline
\end{tabular}

Only nine species of twelve established in the restoration sites by the second year (Table 2). The highest plant cover was found for Festuca pseudovina (47\%) and F. rupicola (29\%). Corynephorus canescens, Galium verum and Salvia pratensis were not established in the restoration sites. Significant positive relationship was detected between field establishment and both laboratory germination $(\mathrm{F}=8.52, \mathrm{df}=1, \mathrm{p}<0.05$ and $\mathrm{F}=7.74, \mathrm{df}=1, \mathrm{p}<0.05$ ) with and without cold-stratification (Figure 2).

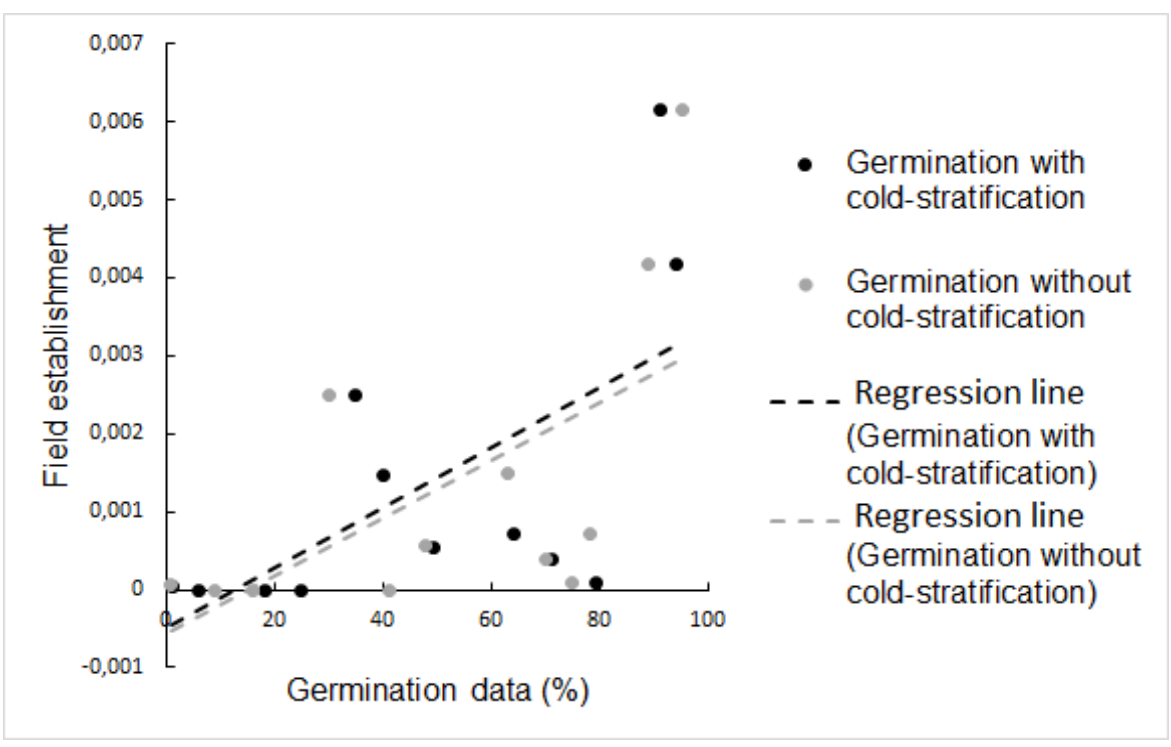

Figure 2. Relationship between second year field establishment and laboratory germination with / without cold-stratification. Germination was based on $4 \times 100$ seeds, field establishment was defined by species cover (\%) weighted by seeding rate. Establishment and laboratory germination with cold-stratification (marked by black) and laboratory germination without cold-stratification (marked by gray). 


\section{Discussion}

\section{Importance of cold-stratification for germination}

The most broadly used and simplest technique for breaking physiological seed dormancy for native species is pre-chilling, or cold-stratification (Baskin and Baskin, 2004; Russell, 2011; Haslgrübler et al., 2013; Jones and Kaye, 2015). Cold-stratification increased germination potential for only one of twelve studied species in this study. The results are in accordance with literature results concerning grasses that do not require cold-stratification for germination (Partzsch, 2010; Russell, 2011; Hardegree et al., 2013, 2016) since they emerge in autumn (Stampfli and Zeiter, 2008). We found even lower germination percentages with cold-stratification than without cold-stratification for four studied grass species. Forbs respond more variably and may require coldstratification (Jones and Kaye, 2015; Wang et al., 2016). However, in our study, out of seven forb species we found only one (Silene vulgaris) germinating better after coldstratification. Silene vulgaris generally does not require cold-stratification (Liu et al., 2008; Partzsch, 2011), only HUSEED wild database (Peti et al., 2017) supported our contrasting results. The reason might be the different behaviour of different seed samples, as found for Eriophyllum lanatum by Russell (2011). In summary, we identified one forb species that need cold-stratification, but most of the studied species did not positively react to this treatment. Other dormancy breaking methods (e.g. mechanical or chemical scarification) should be tested for species with very low germination percentage, like Galium verum or Salvia nemorosa (Liu et al., 2008; Peti et al., 2017). G. verum showed higher germination percentage measured by the Pannon Seed Bank (66\% avg. compared to 6-9 \% in this study, Peti et al. (2017)), $11 \%$ of $S$. nemorosa seeds germinated compared to $1 \%$ in our case, both species after one week of cold treatment. The difference in one order of magnitude can originate from regional differences in population variability. Salvia species often require gibberellic acid to break dormancy (Liu et al., 2008).

\section{Germination and second year field establishment}

As in previous studies (Clarke and Davidson, 2004; Oliveira et al., 2012; Gallagher and Wagenius, 2016), germination was higher under controlled laboratory conditions than under field conditions. This seems self-explanatory, as field conditions imply further constraints that jeopardize establishment ability. Germinated seeds in the field are challenged by abiotic (drought, inappropriate soil conditions (Leishman, 1999; Clarke and Davidson, 2004; Stampfli and Zeiter, 2008; Carrington, 2014) and biotic (competition with existing species (Leishman, 1999; Clarke and Davidson, 2004; Carrington, 2014; Oliveira et al., 2014), allelopathy or the lack of mycorrhizae (Maltz and Treseder, 2015; Koziol and Bever, 2016) factors to develop further and establish.

Laboratory germination with and without cold-stratification was found to be positively connected with second year field plant establishment in this study. This means that the capacity of seeds to germinate has a long-lasting effect on species establishment. Germination success is dependent among others, on seed age, origin, moisture content, and storage conditions (Mondoni et al., 2013), whereas survival in the field can depend on sowing density, timing and seedling characteristics of co-seeded species (Oliveira et al., 2014). Although seeds were sown in the field prior to winter, when moisture and low temperature conditions are most favourable for germination (Commander et al., 2009), 
only four species were well established (field coverage $>0.5 \%$ ), contrary to laboratory results with seven species over $40 \%$ of germination success. Studied species, sown in high density were more successful, than others. Festuca pseudovina germinated and survived best in the study. This species is a matrix forming grass of closed sand steppe adapted to grazing, and the seeds used for restoration originated from cultivation. Perennial grasses were found to establish better also in other studies compared to forbs (Clarke and Davison, 2004). However, the other tested fescue species (F. rupicola, F. vaginata) performed much worse than $F$. pseudovina, and the grey hair-grass (Corynephorus canescens) was not even detected in the field. This suggests that other constrains emerged that might be related to e.g. seed origin, collection time, soil requirements or competition. Based on this the choice of dominant grass species for restoration purposes is a major challenge (Gallagher and Wagenius, 2016).

Only three species out of twelve failed to establish or survive till the second year of restoration and five species reached higher cover than $0.5 \%$. In high diversity mixtures Oliveira and co-workers (2014) found single species being more successful to germinate, establish and grow in the field compared to species mixtures. The performance of target species included in seed mixtures was usually drastically impaired. The unsatisfactory establishment in case of Galium verum, Salvia nemorosa, S. pratensis and Securigera varia, can be explained in part by the special requirements of seeds for breaking dormancy as explained earlier. On the other hand, traits enabling for fast-growing and competitive advantage of dominant species can supress slow growing species and hinder long-term diversity (García-Palacios et al., 2010). Therefore, we suggest using a matrix of grass species (in this case Festuca pseudovina and F. rupicola) for the restoration of dry grasslands diversified with a number of non-competitive forbs.

\section{Conclusions and recommendations}

Germination performance is usually higher in the laboratory than under field conditions (Oliveira et al., 2012), where environmental conditions (both abiotic and biotic) result in lower germination and establishment. Despite environmental limitation, germination percentage in the laboratory and establishment in the field was found to be correlated in this study. This supports the view that laboratory tests of germination or existing germination databases have the potential to help predict establishment success of selected species.

This study provides results to help unfold the relative importance of germination capabilities of species in determining restoration success, as suggested by Larson et al. (2015), but stepping further by measuring second year establishment in the field. Laboratory germination trials are important to understand and predict the processes in the field (Commander et al., 2009). Germination tests can also help estimate the required seed input. During restoration projects seed introduction of several species occur, but the time and available seed quantities represent constrains for testing the germination capability of all sown species. We suggest carrying out quick laboratory germination tests of dominant species to help identify seeding intensity in restoration programmes. Performance of species with low germination result in the laboratory is very hard to predict in the field. In such cases, we can only remain with the general approach to seed higher amounts in the hope of success, unless further knowledge on dormancy is gained to support decision making in order to cope with future needs (Broadhurst et al., 2016). 
Acknowledgments. The authors thank the LEGO group for providing the infrastructure and the Hortobágy National Park Directorate for providing plant material for restoration. Gardening work has been carried out by the Deep Forest Ltd. We thank all collaborators for help in field work. One of the authors was funded by the Hungarian Academy of Sciences (ACs: MTA PD-036/2015, PD-019/2016). More information on the restoration project: http://backtonature.hu/.

\section{REFERENCES}

[1] Aronson, J., Alexander, S. (2013): Ecosystem restoration is now a global priority: time to roll up our sleeves. - Restoration Ecology 21(3): 293-296.

[2] Aszód, L. (1935): Adatok a nyírségi vegetáció ökológiájához és szociológiájához (Data on the vegetation ecology and sociology of Nyírség). - Tiscia 1: 75-107 (in Hungarian).

[3] Baskin, J. M., Baskin, C. C. (2004): A classification system for seed dormancy. Seed science research 14(01): 1-16.

[4] Borhidi, A. (1996): Critical revision of the Hungarian plant communities. - Janus Pannonius University.

[5] Botta-Dukát, Z. (2008): Invasion of alien species to Hungarian (semi-)natural habitats. Acta Botanica Hungarica 50(Supplement 1): 219-227.

[6] Broadhurst, L. M., Jones, T. A., Smith, F. S., North, T., Guja, L. (2016): Maximizing seed resources for restoration in an uncertain future. - BioScience 66(1): 73-79.

[7] Carrington, M. E. (2014): Seed size and recruitment limitation influence seedling establishment in three tallgrass prairie species. - Plant Ecology 215(10): 1163-1172.

[8] Clarke, P. J., Davison, E. A. (2004): Emergence and survival of herbaceous seedlings in temperate grassy woodlands: recruitment limitations and regeneration niche. - Austral Ecology 29(3): 320-331.

[9] Commander, L. E., Merritt, D. J., Rokich, D. P., Dixon, K. W. (2009): Seed biology of Australian arid zone species: germination of 18 species used for rehabilitation. - Journal of Arid Environments 73(6): 617-625.

[10] De Steven, D. (1991): Experiments on mechanisms of tree establishment in old-field succession: seedling survival and growth. - Ecology 72(3): 1076-1088.

[11] Donohue, K., Rubio de Casas, R., Burghardt, L., Kovach, K., Willis, C. G. (2010): Germination, postgermination adaptation, and species ecological ranges. - Annual Review of Ecology, Evolution, and Systematics 41: 293-319.

[12] Gallagher, M. K., Wagenius, S. (2016): Seed source impacts germination and early establishment of dominant grasses in prairie restorations. - Journal of Applied Ecology 53(1): 251-263.

[13] García-Palacios, P., Soliveres, S., Maestre, F. T., Escudero, A., Castillo-Monroy, A.P., Valladares, F. (2010): Dominant plant species modulate responses to hydroseeding, irrigation and fertilization during the restoration of semiarid motorway slopes. Ecological Engineering 36: 1290-1298.

[14] Grime, J. P., Mason, G., Curtis, A. V., Rodman, J., Band, S. R. (1981): A comparative study of germination characteristics in a local flora. - The Journal of Ecology 1017-1059.

[15] Hardegree, S. P., Moffet, C. A., Flerchinger, G. N., Cho, J., Roundy, B. A., Jones, T. A., James, J. J., Clark, P. E., Pierson, F. B. (2013): Hydrothermal assessment of temporal variability in seedbed microclimate. - Rangeland Ecology \& Management 66(2): 127 135.

[16] Hardegree, S. P., Sheley, R. L., Duke, S. E., James, J. J., Boehm, A. R., Flerchinger, G. N. (2016): Temporal variability in microclimatic conditions for grass germination and emergence in the Sagebrush steppe. - Rangeland Ecology \& Management 69(2): 123128. 
[17] Haslgrübler, P., Krautzer, B., Blaschka, A., Graiss, W., Pötsch, E. M. (2013): Quality and germination capacity of seed material harvested from an Arrhenatherion meadow. - Grass and Forage Science 69(3): 454-461.

[18] Hedberg, P., Kotowski, W. (2010): New nature by sowing? The current state of species introduction in grassland restoration, and the road ahead. - Journal for Nature Conservation 18(4): 304-308.

[19] Hendry, G. A., Grime, J. P. (ed.) (1993): Methods in comparative plant ecology: a laboratory manual. - Springer Science and Business Media, London.

[20] Hong, T. D., Ellis, R. H. (1996): A protocol to determine seed storage behaviour. -IPGRI Technical Bulletin No. 1. International Plant Genetic Resources Institute, Rome.

[21] ISTA (2015): International rules for seed testing. - Internation Seed Testing Association, Bassersdorf.

[22] James, J. J., Sheley, R. L., Erickson, T., Rollins, K. S., Taylor, M. H., Dixon, K. W. (2013): A systems approach to restoring degraded drylands. - Journal of Applied Ecology 50(3): 730-739.

[23] John, H., Dullau, S., Baasch, A., Tischew, S. (2016): Re-introduction of target species into degraded lowland hay meadows: How to manage the crucial first year? - Ecological Engineering 86: 223-230.

[24] Jones, K. D., Kaye, T. N. (2014): Factors influencing germination of a functionally important grassland plant, Iris tenax. - PloS One 9(2): e90084.

[25] Jones, K. D., Kaye, T. N. (2015): Growing native seeds for restoration: seed dormancy and germination of Sidalcea malviflora ssp. virgata (Malvaceae). - Natural Areas Journal 35(1): 26-28.

[26] Kaur, J., Schoonmaker, A. L., Sobze, J. M. (2016): Length of cold stratification period affects germination in green alder (Alnus viridis (Chaix) DC. subsp. crispa (Aiton) Turrill) seed collected from northwestern Alberta. - Native Plants Journal 17(2): 95-102.

[27] Kiehl, K., Kirmer, A., Donath, T. W., Rasran, L., Hölzel, N. (2010): Species introduction in restoration projects-Evaluation of different techniques for the establishment of seminatural grasslands in Central and Northwestern Europe. - Basic and Applied Ecology 11(4): 285-299.

[28] Kiehl, K., Kirmer, A., Jeschke, D., Tischew, S. (2014): Restoration of species-rich field margins and fringe communities by seeding of native seed mixtures. - In: Kiehl, K., Kirmer, A., Shaw, N., Tischew, S. (ed.) Guidelines for native seed production and grassland restoration, Chapter 4: 244-273. Cambridge Scholars Publishing, Newcastle.

[29] Király, G. (ed.) (2009): Új magyar füvészkönyv. Magyarország hajtásos növényei. Határozókulcs. Ábrák (New Hungarian herbal. Vascular plants of Hungary. Identification keys). - Aggteleki Nemzeti Park Igazgatóság, Jósvafő (in Hungarian).Kotorová, I., Lepš, J. (1999): Comparative ecology of seedling recruitment in an oligotrophic wet meadow. Journal of Vegetation Science 10(2): 175-186.

[30] Koziol, L., Bever, J. D. (2016): The missing link in grassland restoration: arbuscular mycorrhizal fungi inoculation increases plant diversity and accelerates succession. Journal of Applied Ecology (in press) doi:10.1111/1365-2664.12843.

[31] Krock, S., Smith, S., Elliott, C., Kennedy, A., Hamman, S. T. (2016): Using smoke-water and cold-moist stratification to improve germination of native prairie species. -Native Plants Journal 17(1): 19-27.

[32] Kuhn, M., Weston, S., Wing, J., Forester, J. (2013): The Contrast Package. http://cran.ma.ic.ac.uk/web/packages/contrast/vignettes/contrast.pdf.

[33] Larson, J. E., Sheley, R. L., Hardegree, S. P., Doescher, P. S., James, J. J. (2015): Seed and seedling traits affecting critical life stage transitions and recruitment outcomes in dryland grasses. - Journal of Applied Ecology 52(1): 199-209. 
[34] Leishman, M. R. (1999): How well do plant traits correlate with establishment ability? Evidence from a study of 16 calcareous grassland species. - New Phytologist 141(3): 487-496.

[35] Liu, K., Eastwood, R. J., Flynn, S., Turner, R. M., Stuppy, W. H. (2008): Seed Information Database. - Royal Botanic Gardens, Kew. Retrieved February 28, 2017 from http://www.kew.org/data/sid.

[36] Maltz, M. R., Treseder, K. K. (2015): Sources of inocula influence mycorrhizal colonization of plants in restoration projects: a meta-analysis. - Restoration Ecology 23(5): 625-634.

[37] Merritt, D. J., Dixon, K. W. (2011): Restoration seedbanks - a matter of scale. - Science 332(6028): 424-425.

[38] Mondoni, A., Tazzari, E. R., Zubani, L., Orsenigo, S., Rossi, G. (2013): Percussion as an effective seed treatment for herbaceous legumes (Fabaceae): implications for habitat restoration and agriculture. - Seed Science and Technology 41(2): 175-187.

[39] Oliveira, G., Nunes, A., Clemente, A., Correia, O. (2012): Testing germination of species for hydroseeding degraded Mediterranean areas. - Restoration Ecology 20: 623-630.

[40] Oliveira, G., Clemente, A., Nunes, A., Correia, O. (2014): Suitability and limitations of native species for seed mixtures to re-vegetate degraded areas. - Applied Vegetation Science 17: 726-736.

[41] Partzsch, M. (2010): Zur Keimungsbiologie von zehn ausgewählten xerothermen Grasarten. - Hercynia NF 43: 299-317.

[42] Partzsch, M. (2011): Zur Keimungsbiologie ausgewählter Xerothermrasenarten-Teil 2: Caryophyllaceae. - Hercynia NF 44: 127-144.

[43] Peti, E., Schellenberger, J., Németh, G., Málnási Csizmadia, G., Oláh, I., Török, K., Czóbel, Sz., Baktay, B. (2017): Presentation of the HUSEEDwild - a seed weight and germination database of the Pannonian flora - through analysing life forms and social behaviour types. - Applied Ecology and Environmental Research 15(1): 225-244. Retrieved February 25, 2017 from https://db.nodik.hu:8081/wild.

[44] Pinheiro, J., Bates, D., DebRoy, S., Sarkar, D., Team, R. C. (2016): nlme: Linear and nonlinear mixed effects models. - $\mathrm{R}$ package version 3.1-128, http://CRAN.Rproject.org/package $=$ nlme.

[45] Pyke, D. A., Wirth, T. A., Beyers, J. L. (2013): Does seeding after wildfires in rangelands reduce erosion or invasive species? - Restoration Ecology 21(4): 415-421.

[46] R Core Team (2016): R: A language and environment for statistical computing. - R Foundation for Statistical Computing, Vienna, Austria. URL https://www.R-project.org/.

[47] Romão, C. (1996): Interpretation manual of European Union habitats. - European Commision.

[48] Russell, M. 2011: Dormancy and germination pre-treatments in Willamette Valley native plants. - Northwest Science 85(2): 389-402.

[49] SCBD (2011): Contribution of ecosystem restoration to the objectives of the CBD and a healthy planet for all people. - In: 15th meeting of the subsidiary body on scientific, technical and technological advice of the convention on biological diversity, Montreal.

[50] Sheldon, J. C., Bradshaw, A. D. (1977): The development of a hydraulic seeding technique for unstable sand slopes. I. Effects of fertilizers, mulches and stabilizers. Journal of Applied Ecology 905-918.

[51] Soó, R. (1940): Vergangenheit und Gegenwart der pannonischen Flora und Vegetation. Nova Acta Leopold 9(56): 1-49.

[52] Stampfli, A., Zeiter, M. (2008): Mechanisms of structural change derived from patterns of seedling emergence and mortality in a semi-natural meadow. - Journal of Vegetation Science 19(4): 563-574. 
[53] Suding, K., Higgs, E., Palmer, M., Callicott, J. B., Anderson, C. B., Baker, M., Gutrich, J. J., Hondula, K. L., LaFevor, M.C., Larson, B. M. H., Randall, A., Ruhl, J. B., Schwartz, K. Z. S. (2015): Committing to ecological restoration. - Science 348(6235): 638-640.

[54] Török, P., Vida, E., Deák, B., Lengyel, S., Tóthmérész, B. (2011): Grassland restoration on former croplands in Europe: an assessment of applicability of techniques and costs. Biodiversity and Conservation 20(11): 2311-2332.

[55] Wang, J., Chen, W., Ma, R., Baskin, C. C., Baskin, J. M., Qi, W., Chen, X. (2016): Role of short-term cold stratification on seed dormancy break and germination of alien species in southeastern China. - Plant Ecology 217(4): 383-392.

[56] Williams, M. I., Schuman, G. E., Hild, A. L., Vicklund, L. E. (2002): Wyoming big sagebrush density: effects of seeding rates and grass competition. - Restoration Ecology 10(2): 385-391.

[57] Willis, C. G., Baskin, C. C., Baskin, J. M., Auld, J. R., Venable, D. L., Cavender-Bares, J., Donohue, K., Rubio de Casas, R., The NESCent Germination Working Group (2014): The evolution of seed dormancy: environmental cues, evolutionary hubs, and diversification of the seed plants. - New Phytologist 203(1): 300-309.

[58] Zuur, A. F., Ieno, E. N., Walker, N. J., Saveliev, A. A., Smith, G. M. (2009): Mixed effects models and extensions in ecology with R. - Springer Science and Business Media, New York. 